\title{
PENGELOLAAN KESEHATAN DAN KESELAMATAN KERJA PADA MASA PANDEMI COVID-19: FAKTA DAN TANTANGAN
}

\author{
Wahyuni Diah Ekasari ${ }^{1}$, Suharnomo ${ }^{2}$, Intiyas Utami ${ }^{3}$ \\ ${ }^{1}$ Universitas Terbuka, Jakarta, Indonesia, \\ ${ }^{2}$ Universitas Diponegoro, Semarang, Indonesia, \\ ${ }^{3}$ Universitas Kristen Satya Wacana, Salatiga, Indonesia \\ Email korespondensi: ${ }^{1}$ wahyunidiah.ekasari@gmail.com
}

\begin{abstract}
ABSTRAK
Penelitian ini bertujuan untuk mendeskripsikan implementasi pengelolaan kesehatan dan keselamatan kerja pada masa pandemi Covid-19 pada Kantor Pos Cabang Rembang beserta faktor yang mempengaruhinya. Penelitian ini menggunakan metode analisis data kualitatif dengan pendekatan fenomenologi kritis dengan teknik pengumpulan data melalui observasi, wawancara, penelusuran dokumen, dan dokumentasi. Informan yang dilibatkan sebagai sumber data terdiri dari informan subjek dan informan triangulasi. Hasil dari penelitian ini menunjukkan bahwa pengelolaan kesehatan dan keselamatan kerja pada masa pandemi Covid-19 di Kantor Pos Cabang Rembang sudah mengimplementasikan prinsip protokol kesehatan 5M. Faktor-faktor yang mempengaruhi implementasi pelaksanaan protokol kesehatan 5M pada Kantor Pos Cabang Rembang, meliputi sosialisasi, disiplin, kesadaran, pengawasan, tingkat pendidikan, tingkat kesejahteraan, dan adat kebiasaan. Implikasi hasil penelitian ini adalah meskipun protokol kesehatan 5M tidak mudah untuk dilaksanakan di lingkungan Kantor Pos Cabang Rembang, tetapi dengan adanya sosialisasi masif, kesadaran demi kepentingan bersama, dan kedisiplinan maka implementasi protokol kesehatan 5M dapat dilaksanakan dengan baik.
\end{abstract}

Kata Kunci: kesehatan dan keselamatan kerja; pandemi covid-19; protokol kesehatan 5M

\section{ABSTRACT}

This study aims to describe the implementation of occupational health and safety management during the Covid-19 pandemic at the Rembang branch post office and the factors that influence it. This study uses a qualitative data analysis method with a critical phenomenology approach with data collection techniques through observation, interviews, document searches, and documentation. The informants involved data sources consisted of subject informants and triangulated informants. The results of this study indicate that the management of occupational health and safety during the Covid-19 pandemic at the Rembang Post Office has implemented the principles of the $5 \mathrm{M}$ health protocol. The factors that influence the implementation the $5 \mathrm{M}$ health protocol at the Rembang branch post office include socialization, discipline, awareness, supervision, education level, welfare level, and customs. The implication of the results this study is although the $5 \mathrm{M}$ health protocol is not easy to implement in the Rembang branch post office, but with massive socialization, awareness for the common interest, and discipline, the implementation of the $5 \mathrm{M}$ health protocol can be carried out properly.

Keywords: 5M health protocol; covid-19 pandemic; occupational health and safety

\section{KETERANGAN ARTIKEL}

Riwayat Artikel: diterima: 1 Agustus 2021; direvisi: 3 November 2021; disetujui: 24 Desember 2021.

Klasifikasi JEL: J83, 015

Cara mensitasi: Ekasari, W. D., Suharnomo, \& Utami, I. (2021). Pengelolaan Kesehatan dan Keselamatan Kerja pada Masa Pandemi Covid: Fakta dan Tantangan. JIMFE (Jurnal IImiah Manajemen Fakultas Ekonomi), 7(2), 153-170. https://doi.org/10.34203/jimfe.v7i2.3687 
Wahyuni Diah Ekasari: Pengelolaan Kesehatan dan ...

\section{PENDAHULUAN}

Sumber daya manusia memiliki peran utama dalam sebuah organisasi atau perusahaan. Manusia bertindak sebagai subjek yang wajib diperhatikan oleh pengusaha dan pimpinan organisasi atau perusahaan. Sewu dkk. (2019) menyatakan bahwa kesehatan para karyawan sangat penting bagi keberlanjutan pembangunan, sosial, dan ekonomi, baik pada tingkat global, nasional, regional, maupun lokal. Pengelolaan kesehatan yang baik dan tempat kerja yang aman adalah pondasi agar produktivitas dan kinerja yang lebih baik dan meningkatkan kehidupan kerja yang berkualitas bagi para karyawannya. Fakta ini dinyatakan oleh Health and Safety Executive (HSE) atau sering disebut pelaksana kesehatan dan keselamatan kerja sebagai "Good Health is Good Business", yang artinya bahwa kondisi kesehatan yang prima menunjang keberlanjutan usaha yang produktif (Ridley, 2018).

Walaupun keselamatan dan kesehatan kerja telah menjadi kebutuhan, dalam kenyataannya manusia masih mengabaikan keselamatan. Hal ini terjadi karena keselamatan berkaitan dengan tingkat kesejahteraan dan kebutuhan hidup manusia (Ramli, 2010). Data BPS (Badan Pusat Statistik) Indonesia tentang indikator kesejahteraan rakyat menunjukkan bahwa tingkat kesejahteraan masyarakat Indonesia masih sangat rendah. Hal ini ditunjukkan dengan garis kemiskinan yang mengalami kenaikan setiap tahunnya yang diikuti dengan kenaikan bahan pokok. Garis kemiskinan tahun 2017 adalah sebesar Rp374.478 per kapita per bulan, garis kemiskinan tahun 2018 sebesar Rp401.220 per kapita per bulan, dan garis kemiskinan tahun 2019 sebesar Rp425.250 per kapita per bulan. Menurut data Badan Penyelenggaraan Jaminan Sosial Ketenagakerjaan (BPJS Ketenagakerjaan) telah terjadi peningkatan jumlah kasus kecelakaan kerja dari tahun 2016 sampai dengan akhir September 2019. Data pada tahun 2016 telah terjadi kecelakaan kerja sebanyak 101.368 kasus, tahun 2017 sebanyak 123.041 kasus, tahun 2018 sebanyak 173.415 kasus, dan pada akhir bulan September 2019 tercatat kecelakaan kerja sebanyak 130.923 kasus (Hardum, 2020). Hal tersebut membuktikan bahwa perlindungan keselamatan dan kesehatan kerja di Indonesia ternyata masih sangat minim.

Dessler (2016) menyatakan bahwa pengelolaan kesehatan dan keselamatan kerja yang baik dapat meningkatkan laba perusahaan. Hal ini karena keselamatan kerja yang buruk akan mengakibatkan luka-luka dan penyakit sehingga dapat menaikkan biaya perusahaan, termasuk biaya medis, kompensasi pekerja, dan hilangnya produktivitas. Kepuasan tenaga kerja sangat penting, sebab karyawan dengan tingkat kepuasan kerja yang baik akan bekerja secara produktif sehingga dapat meningkatkan kinerja perusahaan. Apabila karyawan merasa tidak puas, maka akan berakibat menurunnya kinerja karyawan sehingga berdampak pada penurunan kinerja perusahaan. Hal tersebut sesuai dengan penelitian yang dilakukan oleh Wibowo \& Utomo (2016); Kaynak, dkk. (2016); Purnama (2017); Sembe \& Ayuo (2017); Putri, dkk (2018); Safriansyah \& Naim (2019) menyatakan bahwa Keselamatan dan Kesehatan Kerja mempengaruhi kinerja karyawan secara signifikan. Namun hal tersebut berbeda dengan hasil penelitian yang dilakukan oleh Ekowati \& Amin (2018) yang menyatakan bahwa kesehatan dan keselamatan kerja tidak memiliki pengaruh secara langsung pada kinerja karyawan dan kepuasan kerja serta tidak dapat memediasi keselamatan kerja dan kinerja karyawan, sedangkan Ahmad, dkk. (2017) menyatakan bahwa karyawan yang merasa tidak puas dengan hasil kerjanya akan mengakibatkan kinerjanya menjadi buruk, meskipun penerapan kesehatan dan keselamatan kerja telah dilakukan dengan baik di tempat kerja.

Terdapat banyak riset mengenai pengaruh penerapan keselamatan dan kesehatan kerja terhadap kinerja dan kepuasan kerja. Penelitian ini secara spesifik meneliti tentang pengelolaan kesehatan dan keselamatan kerja serta implementasi fakta dan tantangannya di lapangan pada masa pandemi Covid-19. Pada awal tahun 2020 ini terjadi pandemi global yang cukup meresahkan masyarakat, yaitu virus Covid-19 yang memiliki dampak pada tatanan sosial, ekonomi, dan kesehatan. Hal ini mengakibatkan krisis secara global. Goniewicz (2020) mengatakan bahwa krisis adalah semua kejadian yang akan 
mengarah pada situasi ketidakstabilan dan berbahaya yang mepengaruhi individu, kelompok, komunitas, atau seluruh masyarakat. Krisis selalu dianggap sebagai perubahan yang berdampak negatif dalam masalah keamanan, ekonomi, politik, sosial, atau lingkungan, terutama ketika terjadi secara tiba-tiba, dengan sedikit atau tanpa peringatan.

Pada 2 Maret 2020 Presiden Joko Widodo mengumumkan adanya penemuan kasus pasien pertama yang terinfeksi virus Covid-19 di Indonesia. Sejak adanya pengumuman tersebut berbagai upaya dilakukan untuk mencegah penyebaran virus Covid-19 termasuk di lingkungan kerja. Perusahaan dihimbau untuk terus waspada dan meningkatkan upaya perlindungan terhadap pekerja, pengusaha itu sendiri, dan lingkungan masyarakat sekitar terhadap penyebaran virus Covid-19. Upaya untuk pencegahan penularan virus Covid-19 di lokasi kerja antara lain mematuhi peraturan-peraturan terkait Keselamatan dan Kesehatan Kerja (K3). Pada masa pandemi Covid-19 pemerintah telah mengeluarkan berbagai macam bantuan kepada masyarakat yang terdampak pandemi virus Covid-19, salah satunya berupa Bantuan Sosial Tunai dari Kementrian Sosial yang disalurkan melalui PT Pos Indonesia (Persero). Bantuan Sosial Tunai merupakan bantuan yang berupa uang tunai yang diberikan kepada keluarga miskin, tidak mampu, dan/atau rentan yang terkena dampak dari wabah Covid-19.

Kantor Pos Cabang Rembang merupakan salah satu kantor pos yang mengemban tugas untuk menyalurkan dana Bantuan Sosial Tunai tersebut. Dari sumber web Pemerintah Kabupaten Rembang (https://rembangkab.go.id/bansos-bantuan-sosial/), kantor Pos Cabang Rembang mendapat tugas untuk menyalurkan dana Bantuan Sosial Tunai dari Kementrian Sosial RI yang terbagi dalam beberapa tahap dan jumlah KPM (Keluarga Penerima Manfaat yang mencapai puluhan ribu seperti yang tertera di Tabel 1 .

Tabel 1. Data Jumlah KPM (Keluarga Penerima Manfaat) Melalui Pos cabang Rembang

\begin{tabular}{clc}
\hline Tahap & \multicolumn{1}{c}{ Bulan } & Jumlah KPM \\
\hline I & April 2020 & 33.987 \\
II & Mei 2020 & 33.987 \\
II & Juni 2020 & 33.894 \\
IV & Agustus 2020 & 32.259 \\
V & Agustus 2020 & 32.259 \\
VI & September 2020 & 32.321 \\
VII & Oktober 2020 & 32.855 \\
\hline
\end{tabular}

Sumber: https://rembangkab.go.id/bansos-bantuan-sosial/ (2020)

Tugas tersebut merupakan tugas yang tidak mudah karena dilakukan pada masa pandemi Covid-19 dengan total kasus terkonfirmasi yang terus meningkat. Warga diharuskan untuk tetap mematuhi peraturan-peraturan terkait Keselamatan dan Kesehatan Kerja pada masa pandemi Covid-19. Dari https://www.covid19.rembangkab.go.id, data kasus terkonfirmasi Covid-19 di Kabupaten Rembang secara keseluruhan pada Maret 2020 sebanyak satu orang, April 2020 sebanyak tiga orang, bulan Mei 2020 sebanyak lima orang, Juni 2020 sebanyak 68 orang, Juli 2020 sebanyak 216 orang, Agustus 2020 sebanyak 383 orang, September 2020 sebanyak 662 orang, dan Oktober 2020 sebanyak 797 orang. Data tersebut menunjukkan adanya kasus terkonfirmasi Covid-19 yang semakin meningkat. PT Pos Indonesia (Persero) menerapkan serangkaian protokol khusus yang bertujuan untuk mencegah, mengurangi, dan melindungi karyawan dari penyebaran wabah virus Covid-19 di lingkungan PT Pos Indonesia (Persero). 
Wahyuni Diah Ekasari: Pengelolaan Kesehatan dan ...

Saat ini, protokol tersebut telah disosialisasikan di kantor-kantor regional maupun kantor pos di seluruh Indonesia, termasuk pada Kantor Pos Cabang Kabupaten Rembang, Jawa Tengah.

Berdasarkan pemaparan di atas, maka penelitian ini bertujuan untuk mendeskripsikan implementasi pengelolaan kesehatan dan keselamatan kerja pada masa pandemi Covid-19 pada Kantor Pos Cabang Rembang beserta faktor yang mempengaruhinya. Penelitian ini secara teoritis diharapkan dapat memberikan informasi mengenai kesehatan dan keselamatan kerja pada masa pandemi virus Covid-19 melalui penerapan protokol kesehatan 5M dan juga pengembangan ilmu Ekonomi Manajemen pada umumnya dan Manajemen Sumber Daya Manusia pada khususnya. Penelitian ini diharapkan dapat memberikan informasi tentang pengelolaan, implementasi, tantangan serta solusi pada pelaksanaan protokol kesehatan 5M pada masa pandemi virus Covid-19. Manfaat praktis dari penelitian ini adalah dapat membantu manajemen Kantor Pos Cabang Rembang untuk memberikan motivasi agar terus mensosialisasikan dan menerapkan disiplin protokol kesehatan baik bagi karyawan dan konsumen Kantor Pos Cabang Rembang demi kepentingan bersama. Selain itu, penelitian ini memberikan kontribusi dalam membantu subjek menemukan solusi untuk mengatasi kendala pelaksanaan pengelolaan kesehatan dan keselamatan kerja pada masa pandemi virus Covid-19.

\section{KAJIAN LITERATUR}

\section{Kesehatan dan Keselamatan Kerja}

Kesehatan dan keselamatan kerja atau disingkat dengan istilah K3 muncul bersamaan dengan revolusi industri di Eropa, terutama di Inggris, Jerman, dan Perancis, serta revolusi industri yang terjadi di Amerika Serikat. Di Indonesia sendiri kesadaran akan K3 sudah ada sejak pemerintahan Kolonial Belanda yaitu dengan adanya penerbitan Veiligheids Reglement, Staatsblad No. 406 Tahun 1910 oleh Pemerintah Belanda. Pada awal kemerdekaan RI aspek K3 belum menjadi isu strategis namun menjadi bagian dari permasalahan kemanusiaan dan keadilan. Pada tahun 1970-an permasalahan K3 baru menjadi perhatian searah dengan semakin berkembangnya investasi modal dan manufaktur di Indonesia. Pada era globalisasi pembangunan di Indonesia selalu berkaitan dengan hak asasi manusia, lingkungan hidup, kemiskinan, dan buruh. Pada era globalisasi dan digitalisasi sekarang ini terjadi persaingan secara global tidak hanya kualitas barang saja akan tetapi terjadi juga persaingan kualitas dari pelayanan dan jasa. Semua perusahaan diwajibkan melaksanakan program Kesehatan dan Keselamatan Kerja. Bahkan banyak perusahaan multinasional menempatkan syarat utama pelaksanaan program Kesehatan dan Keselamatan Kerja sebagai syarat berinvestasi.

Purnama (2017) menyatakan bahwa kesehatan kerja adalah sebuah ilmu kesehatan yang memiliki tujuan agar karyawan mendapatkan kesehatan yang prima baik itu secara fisik, mental, dan social sehingga dapat bekerja dengan optimal. Endro \& Utomo (2016) berpendapat bahwa keselamatan kerja adalah segala bentuk perlindungan terhadap karyawan dari cedera akibat kecelakaan yang berhubungan dengan pekerjaan yang dilakukan. Kesehatan dan keselamatan kerja adalah ilmu untuk mengantisipasi, merekoginis, mengevaluasi, dan mengendalikan bahaya-bahaya yang dapat terjadi di tempat kerja dan berdampak bagi kesehatan fisik dan mental karyawan, serta dampak yang mungkin dirasakan oleh masyarakat dan lingkungan sekitar (Sembe \& Ayuo, 2017).

Panggabean (2016) menyatakan bahwa perusahaan memiliki program keselamatan dan kesehatan kerja yang bertujuan untuk meminimalkan tingkat kecelakaan kerja sampai nol (zero acident). Beberapa hal yang harus dilakukan oleh perusahaan agar zero acident tercapai, antara lain taat asas terhadap peraturan keselamatan dan kesehatan kerja yang dikeluarkan oleh pemerintah, membuat prosedur dan manual tentang bagaimana mengatasi keselamatan kerja, adanya pelatihan dan sosialisasi tentang keselamatan dan kesehatan kerja kepada karyawan, adanya fasilitas keselamatan, dan kesehatan kerja yang optimum, serta bertanggung jawab atas keselamatan dan kesehatan para karyawan. Panggabean 
(2016) juga berpendapat bahwa apabila semua unsur di dalam perusahaan mendukung, maka tujuan dari keselamatan dan kesehatan kerja dapat dicapai. Unsur-unsur tersebut, antara lain adanya dukungan dari pimpinan puncak, dengan ditunjuknya direktur keselamatan, rekayasa pabrik dan kegiatan yang aman, diberikannya pelatihan bagi semua karyawan untuk berperilaku aman, adanya catatan-catatan tentang kecelakaan kerja, menganalisis penyebab kecelakaan kerja, adanya kontes keselamatan, dan melaksanakan peraturan yang berlaku.

Manfaat keselamatan dan kesehatan kerja dapat juga dilihat dari pendekatan ekonomi atau finansial. Kecelakaan dapat menimbulkan dampak kerugian yang sangat besar bagi perusahaan. Banyak perusahaan atau organisasi yang harus gulung tikar karena kecelakaan, bencana alam, atau dampak keselamatan dan kesehatan kerja lainnya yang terjadi dalam operasinya. Dampak ekonomi dari keselamatan dan kesehatan kerja dapat dilihat dari sisi produktivitas dan pengendalian kerugian (loss control). Kecelakaan dapat mempengaruhi produktivitas perusahaan. Di dalam proses produksi, produktivitas ditopang oleh tiga pilar utama, yaitu kuantitas (quantity), kualitas (quality), dan keselamatan (safety) (Ramli, 2018). Produktivitas hanya dapat tercapai apabila ketiga unsur produktivitas di atas berjalan secara seimbang.

Penyebaran dan penularan virus Covid-19 terjadi pada awal tahun 2020 dan menjadi pandemi global dimana sangat berpengaruh pada sektor ekonomi. Ditjen Pembinaan Pengawasan Ketenagakerjaan dan K3 menerbitkan Surat Edaran bernomor B.5/51/AS.0202/1/2020 yang isinya berupa himbauan kepada seluruh kepala Dinas Ketenagakerjaan dan pimpinan perusahaan untuk waspada terhadap penyebaran penyakit pneumonia berat yang tidak diketahui penyebabnya pada pekerja. Bagi para pimpinan perusahaan dalam Surat Edaran Dirjen Pengawasan ini menghimbau tentang empat hal, yaitu melaksanakan Permenakertrans No. 22 Tahun 1980 tentang Pemeriksaan Kesehatan Tenaga Kerja dalam Penyelenggaraan Keselamatan Kerja secara berkala, dan Permenakertrans No. 03 Tahun 1982 tentang Pelayanan Kesehatan Kerja sebagai bagian dari Penerapan Syarat-Syarat K3. Kedua, melakukan upaya pencegahan seperti menjaga kebersihan lingkungan kerja, dan menjaga kebersihan tangan dengan cara mencuci tangan. Ketiga, memberikan informasi kepada pekerja tentang kasus pneumonia berat. Keempat, berkoordinasi dengan pihak terkait dalam upaya pencegahan penyebaran pneumonia berat di lokasi kerja.

\section{Pandemi Covid-19}

Covid-19 pertama kali diidentifikasi di kota Wuhan, China, pada akhir bulan Desember 2019 dan merupakan penyakit yang disebabkan oleh tipe baru coronavirus (SARS-CoV-2). Virus ini menyebar dengan cepat ke wilayah lain di Cina dan juga seluruh negara di dunia. Pada 20 Januari 2020, Goniewicz (2020) menyatakan bahwa ada informasi kasus penyebaran virus Covid-19 yang terkonfirmasi dari Thailand, Jepang, dan Korea Selatan. Selama wabah Covid-19, Cina telah mengubah beberapa kali definisi kasus, yang mengakibatkan ketidakpastian mengenai jumlah pasti kasus dan tingkat penyebaran virus ini. World Health Organization (WHO) sebagai lembaga kesehatan dunia merespon dengan mengoordinasikan negara-negara di dunia dan telah menyatakan Covid-19 sebagai pandemi global pada 11 Maret 2020.

WHO menyatakan bahwa Covid-19 merupakan penyakit sangat menular yang diakibatkan oleh jenis coronavirus yang baru ditemukan. Seseorang dapat tertular virus Covid-19 dari orang lain yang sudah terjangkit virus ini. Virus Covid-19 dapat menyebar dari seorang ke orang lain di sekitarnya melalui doplet dari hidung ataupun mulut yang keluar dari seseorang yang sudah terinfeksi virus Covid-19 dari batuk atau bersin. Doplet ini kemudian jatuh ke benda-benda disekitarnya dan apabila seseorang menyentuh benda tersebut kemudian menyentuh mata, hidung, ataupun mulutnya, dapat terinfeksi 
Wahyuni Diah Ekasari: Pengelolaan Kesehatan dan ...

virus Covid-19. Penularan virus Covid-19 juga dapat terjadi jika seseorang menghirup doplet yang keluar dari batuk atau bersin orang yang sudah terinfeksi virus Covid-19.

WHO dan Kemenkes RI mensosialisasikan delapan cara untuk mengurangi risiko terinfeksi virus Covid-19 antara lain: (1) menerapkan pola hidup sehat dan bersih, salah satu caranya dengan sering mencuci tangan dengan sabun dan air yang mengalir; (2) memakai masker berlapis dengan baik dan benar; (3) Menjaga jarak dan tidak berkerumun; 4) menjaga jarak dan tidak berkerumun; 5) melakukan test dan tracing secara masif; (6) memperbanyak informasi terbaru mengenai perkembangan Covid-19 dan menghindari berita hoax; (7) segera berobat ketika sakit; (8) membatasi akses keluar masuk wilayah dan bagi masyarakat yang hendak ke luar negeri sebaiknya lebih waspada (Alfarizi, 2021).

\section{Protokol Kesehatan 5M}

Penyakit yang disebabkan oleh virus Covid-19 telah mengakibatkan krisis diberbagai bidang termasuk krisis kesehatan dan krisis ekonomi secara global yang berdampak besar pada cara pandang orang dalam memahami dunia dan kehidupan sehari-hari. Sampai saat ini metode penularan Covid-19 memang belum dapat ditentukan secara pasti, hal ini disebabkan penelitian tentang virus Covid-19 masih selalu berkembang dan mutasi virus Covid-19 terus masih terus terjadi sehingga pemerintah merekomendasikan kepada masyarakat agar selalu waspada.

Langkah-langkah untuk mencegah penularan dan penyebaran virus Covid-19 telah dilakukan oleh pemerintah salah satunya dengan mensosialisasikan protokol kesehatan $5 \mathrm{M}$, yaitu Mencuci tangan dengan sabun dan air yang mengalir selama 20 detik sebelum dan sesudah melakukan aktivitas, Memakai masker berlapis dengan baik dan benar saat beraktivitas di luar rumah, Menjaga jarak aman setidaknya satu meter terutama pada saat berada di tempat fasilitas umum, Menjauhi kerumunan saat berada di luar rumah karena seseorang yang memiliki intensitas tinggi bersosialisasi dengan banyak orang memiliki resiko yang lebih tinggi terinfeksi virus Covid-19, Mengurangi mobilitas karena semakin tinggi intensitas keluar rumah maka akan semakin tinggi terinfeksi virus Covid-19 sehingga apabila tidak ada kepentingan mendesak disarankan untuk berada di rumah (Alfarizi, 2021). Selain protokol kesehatan $5 \mathrm{M}$, pencegahan penularan Covid-19 dapat dilakukan dengan cara mengkonsumsi multivitamin, makan makanan yang bergizi seimbang, dan berolahraga secara teratur untuk menjaga daya tahan tubuh, serta melakukan vaksinasi Covid-19.

\section{Kedisiplinan Karyawan}

Disiplin merupakan kemauan dan kehendak seorang karyawan untuk menaati semua peraturan dan norma sosial yang berlaku di perusahaan. Pada masa pendemi Covid-19 semua karyawan tanpa terkecuali harus disiplin menerapkan protokol kesehatan 5M. Semua karyawan secara sukarela mematuhi protokol kesehatan $5 \mathrm{M}$ dan menyadari akan tugas serta tanggung jawabnya dilingkungan tempat kerja. Kunci sukses menghadapi pendemi Covid-19 adalah dengan disiplin menerapkan protokol kesehatan 5M baik di lingkungan kerja, di tempat umum, maupun di dalam lingkungan keluarga. Bagitu juga dalam manajemen sumber daya manusia kedisipilnan adalah fungsi operatif yang sangat penting, hal ini disebabkan semakin baik tingkat kedisiplinan seorang karyawan maka semakin tinggi prestasi kerja yang dapat dihasilkan oleh karyawan tersebut.

\section{METODE PENELITIAN}

Penelitian ini adalah penelitian yang mendeskripsikan dan menganalisis fenomena, kegiatan sosial, sikap, kepercayaan, persepsi, pemikiran seseorang baik secara individu ataupun secara kelompok. Jenis penelitian ini adalah penelitian kualitatif. Dalam penelitian ini digunakan istilah informan sebagai sampel pada penelitian kualitatif dengan pendekatan fenomenologi kritis. Informan dalam penelitin ini 
berjumlah sepuluh orang yang terdiri dari: informan subjek, yaitu satu orang kepala Kantor Pos Cabang Rembang, dua orang petugas loket Kantor Pos Cabang Rembang, satu orang petugas kurir Kantor Pos Cabang Rembang, dan satu orang oranger pos; informan triangulasi, yaitu satu orang Kabid P2 Dinas Kesehatan Kabupaten Rembang, satu orang pelanggan pos sebagai penerima dana bantuan sisoal tunai, dan tiga orang pelanggan pos sebagai pengguna jasa pos.

Kegiatan pengambilan data dilakukan selama satu bulan, yaitu dari tanggal 12 Agustus 2020 hingga 12 September 2020. Metode pengumpulan data yang dilakukan dalam penelitian ini adalah sebagai berikut: penelitian lapangan merupakan penelitian yang dilakukan dengan cara melakukan penelitian secara langsung kepada objek penelitian untuk mendapatkan data primer, yaitu kantor Pos cabang Kabupaten Rembang, Jawa Tengah. Pengumpulan data dilakukan melalui: observasi/pengamatan, wawancara, dan dokumentasi; studi kepustakaan merupakan mencari buku-buku literatur ataupun e-book dan e-journal dari halaman web yang sesuai dengan masalah yang diangkat, dan informasi yang telah didapatkan digunakan untuk memecahkan permasalahan yang berkaitan dengan penelitian yang sedang diteliti; triangulasi merupakan teknik pemeriksaan keabsahan data atau informasi yang diperoleh peneliti dari berbagai sudut pandang yang berbeda dengan cara mengurangi sebanyak mungkin bias yang terjadi pada saat pengumpulan data dan analisa data. Triangulasi yang digunakan pada penelitian ini adalah triangulasi sumber. Triangulasi sumber merupakan teknik membandingkan dan mengecek balik derajat kepercayaan suatu informasi yang telah diperoleh melalui waktu dan alat yang berbeda dalam penelitian kualitatif. Hal ini dicapai dengan cara membandingkan hasil wawancara informan penelitian yang lain.

Penelitian ini menggunakan pendekatan triangulasi data atau sumber, yaitu dengan cara mengumpulkan data dari berbagai sumber, antara lain beberapa informan subjek yang terdiri dari kepala kantor pos, petugas loket, petugas pengantar pos dan petugas oranger, serta informan triangulasi yang terdiri dari Kabid P2 Dinas Kesehatan Kabupaten Rembang dan konsumen kantor pos yang memiliki karakteristik yang berbeda, serta mengumpulkan data-data dari dokumen dan literatur yang mengacu pada permasalahan penelitian. Semua informasi yang diperoleh selalu dibandingkan dan diuji dengan data/informasi yang lain untuk mengecek kepercayaan suatu informasi yang telah diperoleh melalui waktu dan alat yang berbeda.

Setelah semua data terkumpul, maka langkah selanjutnya adalah melakukan pengolahan dan analisis data. Analisis data merupakan suatu proses untuk mencari dan menyusun secara sistematis data-data yang telah diperoleh dari hasil, wawancara, catatan lapangan, serta dokumentasi, dengan cara mengorganisasikan data kedalam kategori, menjabarkannya kedalam unit-unit, melakukan sintesa, menyusunnya kedalam pola memilih mana yang penting dan akan dipelajari. Analisis data yang digunakan dalam penelitian ini menggunakan analisis data kualitatif dengan pendekatan fenomenologi kritis, yaitu penelitian yang dirancang untuk menemukan hakikat dari fenomena atau gejala yang tampak dan dialami oleh individu atau sekelompok individu dengan cara mendiskripsikan, menganalisis, dan mentafsirkan pola perilaku, kepercayaan, dan bahasa yang berkembang sepanjang waktu (Hamzah, 2020).

\section{HASIL DAN PEMBAHASAN}

\section{Kantor Pos Cabang Rembang}

Aktifitas utama dari kantor pos cabang, yaitu membuat job discription di kantor pos cabang sesuai dengan ketentuan yang berlaku sebagai pedoman kerja; memastikan bahwa pelaksanaan pekerjaan di kantor pos cabang telah sesuai dengan SOP dan ketentuan perusahaan; melakukan penerimaan transaksi layanan paket, keagenan, BPM dan benda filateli, pelayanan jasa surat, jasa keuangan, tabungan, giro 
Wahyuni Diah Ekasari: Pengelolaan Kesehatan dan ...

dan penyaluran dana, pembayaran pensiun, dan pembayaran wesel pos; mempertanggujawabkan transaksi penerimaan dan pengeluaran keuangan yang terjadi di kantor pos cabang pada daftar pertanggungan N2; melakukan permintaan benda pos, materai, perangko dan benda filateli; melakukan tutupan surat dan paket yang akan dikirimkan ke kantor pos pemeriksa yang bertalian setiap hari sesuai dengan jadwal tutupan yang telah ditetapkan kantor pos pemeriksa; mencocokkan uang hasil penerimaan dan pembayaran transaksi keuangan di kantor pos cabang dengan naskah dan dokumen sumber bertalian; mengirimkan naskah pertanggungan keuangan, dokumen sumber, resi-resi transaksi bersamaan dengan kiriman pos di dalam kantung pos ke kantor pos pemeriksa; membuka kantong pos yang diterima dari kantor pos pemeriksa dihadapan saksi; dan mengawasi pelaksanaan antaran surat dan paket yang dilakukan oleh pengantar pos di kantor pos cabang serta pemeriksaan terhadap sisa antaran. Berikut adalah gambar struktur oganisasi dari Kantor Pos Cabang Rembang.

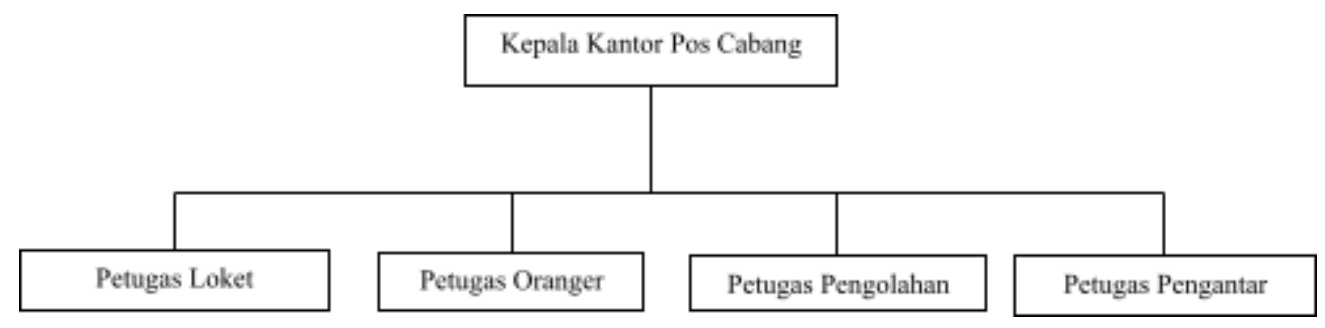

Gambar 1. Struktur Organisasi Kantor Pos Cabang Rembang

Seperti yang telah diuraikan dari Tabel 1, PT Pos Indonesia (Persero) dalam masa pandemi virus Covid-19 ini juga mendapatkan amanah untuk menyalurkan Bantuan Sosial Tunai dari Kementrian Sosial. Tugas tersebut tidaklah mudah karena Kabupaten Rembang merupakan kabupaten dengan fasilitas kesehatan di rumah sakit yang terbatas, jumlah karyawan kantor pos yang terbatas, dan luas Kantor Pos Cabang Rembang yang tidak begitu luas, pihak kantor pos harus dapat meyalurkan dana Bantuan Sosial Tunai yang jumlahnya puluhan ribu KPM (Keluarga Penerima Manfaat) di masa pandemi Covid-19, jumlah terkonfirmasi Covid-19 di Kabupaten Rembang yang terus meningkat setiap bulannya (lihat Gambar 2). Grafik Perkembangan Kasus Covid-19 di Kabupaten Rembang) dengan kewajiban mematuhi peraturan-peraturan terkait keselamatan dan kesehatan kerja secara disiplin yang kita kenal dengan istilah mematuhi protokol kesehatan secara ketat agar tidak menjadi cluster penyebaran virus Covid-19 tidaklah mudah. Hal ini menjadi persoalan tersendiri terutama masalah social distancing, kecukupan tempat cuci tangan dan sabun, dan kecepatan pelayanan pada saat pencairan dana, karena melihat data alokasi dana yang mencapai puluhan ribu penerima dana Bantuan Sosial Tunai. 


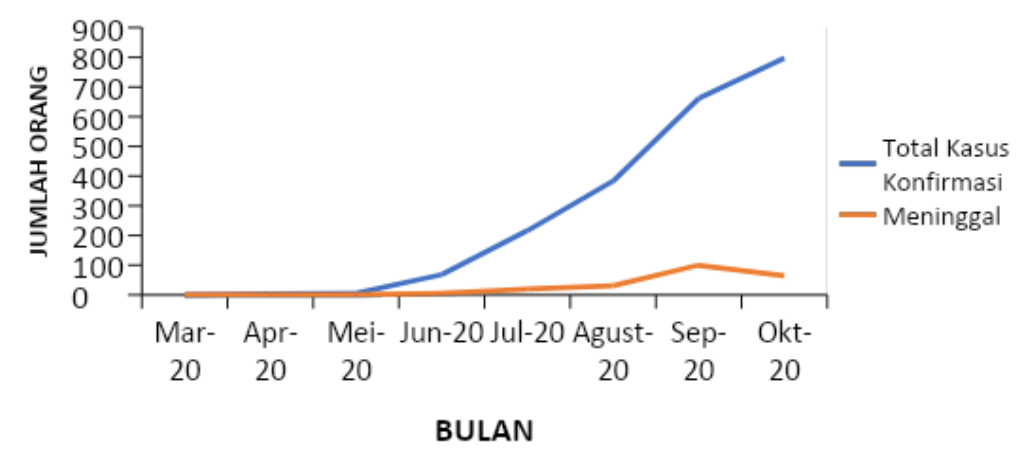

Gambar 2. Grafik Perkembangan Kasus Covid-19 Di Kabupaten Rembang

Sumber: https://www.covid19.rembangkab.go.id (2020)

Pengetahuan Subjek Penelitian Tentang Pengelolaan Kesehatan Kerja dan Keselamatan Kerja Pada Masa Pandemi Covid-19

Sebelum adanya pandemi Covid-19 pengelolaan Kesehatan dan Keselamatan Kerja pada Kantor Pos Cabang Rembang, antara lain bagi petugas kuris pos dan oranger pos diwajibkan memakai helm, memakai jaket, membawa SIM dan STNK pada saat melaksanakan tugasnya. Bagi petugas loket Kantor Pos Cabang Rembang tidak ada kewajiban memakai masker dan mencuci tangan. Bagi pelanggan Kantor Pos Cabang Rembang tidak ada kewajiban untuk memakai masker dan mencuci tangan saat datang ke kantor pos, tidak ada pengaturan jarak pada tempat duduk saat mengantri. Kantor Pos Cabang Rembang tidak menyediakan sarana tempat cuci tangan didekat pintu masuk kantor pos. Hal ini dapat disimpulkan bahwa sebelum terjadinya pandemi Covid-19 protokol kesehatan 5M tidak dilaksanakan pada Kantor Pos Cabang Rembang.

Kasus positif Covid-19 di Indonesia belum juga menunjukkan grafik yang menurun hingga saat ini. Hal ini menjadikan perhatian khusus bagi semua pihak untuk terus mengingatkan tentang pentingnya protokol kesehatan $5 \mathrm{M}$ di era new normal. Sejalan dengan langkah-langkah pencegahan penyebaran virus Covid-19 yang terus dikembangkan oleh pemerintah, PT Pos Indonesia (Persero) secara konsisten dan disiplin melakukan upaya minimalisir penyebaran virus Covid-19 di lingkungan kantor pos untuk melindungi petugas pos dan pelanggan pos. Kantor Pos Cabang Rembang Jawa Tengah sebagai salah satu perusahaan pelayanan publik yang memiliki tugas pokok menyelenggarakan jasa pos dan giro, jasa keuangan, dan jasa keagenan melaksanakan pengelolaan Kesehatan dan Keselamatan Kerja di masa pandemi Covid-19 dengan menerapkan protokol kesehatan 5M untuk melindungi petugas pos dan pelanggan pos. Protokol kesehatan 5M tersebut antara lain yaitu Memakai masker, Mencuci tangan dengan sabun dan air mengalir sebelum dan sesudah memasuki kantor pos dengan cara yang benar, Menjaga jarak minimal satu meter dengan karyawan ataupun pelanggan yang lain, Menjauhi kerumunan, dan Mengurangi mobilitas.

Pertanyaan kesatu: apa saja kebijakan yang diterapkan oleh Kantor Pos Cabang Rembang yang berkaitan dengan pengelolaan Kesehatan dan Keselamatan Kerja di masa pandemi virus Covid-19?

Berikut kutipan dan jawaban informan subjek:

Informan pertama, Ibu DP selaku kepala cabang Kantor Pos Cabang Rembang menyatakan bahwa, 
Wahyuni Diah Ekasari: Pengelolaan Kesehatan dan ...

“... kebijakan yang diterapkan Kantor Pos Cabang Rembang yang berkaitan dengan pencegahan penyebaran virus Covid-19 sedikit berbeda menurut tugas dan tanggung jawabnya, misalnya bagi pegawai pos di kantor yaitu mencuci tangan sebelum dan sesudah memasuki kantor pos; wajib memakai masker; melakukan phisical distancing; memakai sarung tangan; bagi pegawai di lapangan (pengantar dan oranger) wajib memakai jaket, helm, masker, dan sarung tangan, mencuci tangan sebelum memasuki kantor; sedangkan bagi pelanggan pos: mencuci tangan sebelum dan sesudah memasuki kantor pos, wajib memakai masker, tidak berkumpul/menjaga jarak minimal satu meter dengan karyawan/pelanggan yang lain ..."

Pernyataan yang sama juga dinyatakan oleh Bapak AL dan Ibu UM sebagai petugas loket Kantor Pos Cabang Rembang beliau menyatakan,

"... setau saya Mbak, kebijakan yang diterapkan Kantor Pos Cabang Rembang tentang protokol kesehatan di masa pandemi virus covid-19 antara lain mencuci tangan dengan sabun, menjaga jarak, wajib memakai masker, menjaga kesehatan dan kebersihan, jika merasa tidak enak badan sebaiknya ijin tidak masuk kerja karena setiap breafing pagi kami semua selalu diingatkan akan hal-hal tersebut ..."

Bapak HD yang bertugas sebagai kurir Kantor Pos Cabang Rembang dan Bapak PN sebagai petugas oranger pos juga menyatakan hal yang sama, beliau menyatakan bahwa,

"... begini Mbak untuk kami petugas kurir pos kebijakan yang diterapkan Kantor Pos Cabang Rembang tentang protokol kesehatan di masa pandemi virus Covid-19 antara lain mencuci tangan dengan sabun, menjaga jarak, wajib memakai masker, memakai helm, memakai sarung tangan dan jaket saat bertugas, jadi sedikit berbeda dengan petugas loket pos karena kami lebih sering di lapangan, keliling berkendara dengan motor ..."

Berikut kutipan dan jawaban informan triangulasi :

Pernyataan tersebut diperkuat oleh Ibu RA sebagai informan triangulasi selaku konsumen Kantor Pos Cabang Rembang sebagai penerima dana Bantuan Sosial Tunai dari kementrian Sosial bahwa,

"... sejak ono covid mbak yen metu omah kudu nganggo masker, yen meh mlebu misale ke kantor pos, kantor polisi, samsat, pasar, utowo bank kudu wisuh tangan lan dicek suhu badan, ora oleh grombol-grombol mbak, ora oleh pengajian juga arisan kampong..."

Terjemahan:

"... semenjak ada covid jika keluar rumah harus menggunakan masker, jika hendak masuk misalnya ke kantor pos, kantor polisi, samsat, pasar, ataupun bank harus cuci tangan terlebih dahulu dan dicek suhu tubuhnya, tidak boleh berkerumun, tidak boleh pengajian maupun arisan di kampung ..."

Pernyataan yang sama juga disampaikan oleh Bapak AR sebagai informan triangulasi yang bertugas sebagai Kabid P2 Dinas Kesehatan Kabupaten Rembang,

"... Sebenarnya tidak ada kebijakan khusus mengenai protokol kesehatan di masa pandemi ini bagi kantor pos sebagai salah satu kantor pelayanan publik di Kota Rembang. Namun dari kami Dinas Kesehatan selalu mensosialisasikan adanya protokol kesehatan yang berlaku bagi semua kantor, tempat umum, tempat pelayanan publik, pasar, toko, rumah makan, dan tempat wisata adalah sama yang perpegangan kepada Surat Edaran yang dikeluarkan oleh Bapak Bupati Rembang, yaitu Surat Edaran (SE) Nomor 440/0716/2020 tentang Peningkatan Kewaspadaan terhadap Risiko Penularan Infeksi Corona Virus Disease (Covid-19) di Kabupaten Rembang, bahwa setiap kantor harus menyediakan sarana cuci tangan dan sabun, wajib masker, karyawan yang sakit diwajibkan untuk tidak masuk kerja dan berobat, melakukan social distancing. Surat Edaran tersebut merupakan tindak lanjut dari Instruksi Presiden RI dan Gubernur Jawa Tengah guna meminimalkan penyebaran virus corona yang telah ditetapkan oleh WHO sebagai pandemik global ..."

Implementasi Protokol Pencegahan Penyebaran Virus Covid-19 di Kantor Pos Cabang Rembang 
Program kesehatan dan keselamatan kerja merupakan salah satu cara untuk melindungi karyawan dari bahaya terjadinya kecelakaan selama bekerja. Selain untuk melindungi karyawan dari terjadinya kecelakaan, sebuah perusahaan juga perlu memelihara kesehatan para karyawanannya, baik itu menyangkut kesehatan fisik maupun kesehatan mental. Kesehatan para karyawan dapat terganggu karena penyakit ataupun karena kecelakaan. Oleh sebab itu, program kesehatan kerja dan keselamatan kerja perlu dilaksanakan secara efektif oleh suatu perusahaan, karena hal ini dapat menurunkan frekuensi kecelakaan disamping itu dengan terjaganya kesehatan para karyawan dapat meningkatkan semangat kerja dan dapat meningkatkan produktivitas perusahaan. Terlebih dimasa pandemi Covid-19 ini faktor kesehatan kerja para karyawan perlu mendapat perhatian khusus.

Pertanyaan kedua: bagaimana implementasi protokol kesehatan pencegahan penyebaran virus Covid-19 yang telah diterapkan pada Kantor Pos Cabang Rembang?

Berikut kutipan dan jawaban informan subjek:

Ibu DP selaku kepala Kantor Pos Cabang Rembang menjelaskan bahwa,

“... Pelaksanaan kebijakan protokol kesehatan pada masa pandemi Covid-19 yang sudah diterapkan Kantor Pos Cabang Rembang, antara lain bagi pegawai pos di kantor yaitu mencuci tangan dengan sabun dan air mengalir sebelum dan sesudah memasuki kantor pos dengan cara yang benar, wajib memakai masker, memakai hand sanitiser setelah melakukan transaksi dengan pelanggan, tidak berkumpul/menjaga jarak minimal satu meter dengan karyawan/pelanggan yang lain, karyawan yang sakit disarankan untuk tidak masuk kerja/ijin, pengecekan suhu tubuh dengan termogun pada setiap karyawan sebelum melakukan absensi; bagi pegawai di lapangan (pengantar dan oranger) yaitu wajib memakai jaket, helm, masker, dan sarung tangan, pada saat pembagian Bantuan Sosial Tunai (BST) petugas pos wajib memakai masker, faceshield, dan sarung tangan. Masker medik hanya untuk petugas yang akan membagikan dana Bantuan Sosial Tunai dari Dinas Sosial karena pada saat ini masker medik sangat susah dicari di kota Rembang dan berinteraksi dengan banyak orang, maka dari itu jika tidak sedang bertugas membagikan BST memakai masker kain lapis dua. Sedangkan bagi pelanggan pos yaitu mencuci tangan dengan sabun dan air mengalir sebelum dan sesudah memasuki kantor pos dengan cara yang benar, wajib memakai masker, tidak berkumpul/menjaga jarak minimal satu meter dengan karyawan/pelanggan yang lain, dilarang duduk ditempat duduk yang diberi tanda silang, loket pelayanan diberi pembatas dari mika bening. Seiring mengikuti perkembangan tentang penyebaran virus Covid-19 dapat menyebar melalui udara maka pada kantor untuk pintu dan jendela kami buka dan AC dimatikan agar sirkulasi udara bagus dalam ruangan ..."

Hal ini sesuai dengan pernyataan Bapak AL dan Ibu UM yang bertugas melayani di loket kantor pos Rembang menyatakan bahwa,

"... pelaksanaan protokol kesehatan yang sudah dilaksanakan Kantor Pos Cabang Rembang yaitu mencuci tangan dengan sabun sebelum dan sesudah memasuki kantor pos, wajib memakai masker, menjaga jarak, pengecekan suhu tubuh sebelum melakukan absensi, apabila termogun menunjukkan suhu di atas $37.5^{\circ} \mathrm{C}$ maka diwajibkan untuk pulang beristirahat dirumah, menjaga kesehatan dan kebersihan lingkungan kerja, loket pelayanan diberi sekat pembatas dari mika bening, AC pada ruangan dimatikan sedangkan pintu dan jendela kami buka untuk sirkulasi udara ..."

Berikut kutipan dan jawaban informan triangulasi:

Pernyataan tersebut diperkuat oleh Ibu RA selaku konsumen Kantor Pos Cabang Rembang sebagai penerima dana Bantuan Sosial Tunai dari Kementrian Sosial bahwa,

"... oh iyo mb abene neng kantor pos jupuk dana bantuan kudu nganggo masker, sak durunge mlebu kantor pos wisuh tangan lan dicek suhu badane nganggo alat koyo tembak diarahke neng tangan kiwo, pas antri panggonan lungguh wes diatur mbak jadi renggang jarake, gowo KTP asli lan surat undangan soko desa lan kantor pos bab penerimaan dana bantuan ..." 
Wahyuni Diah Ekasari: Pengelolaan Kesehatan dan ...

Terjemahan:

"... oh iya mbak setiap datang ke kantor pos untuk mengambil dana bantuan diharuskan memakai masker, sebelum masuk kekantor pos diwajibkan mencuci tangan dan ada pengecekan suhu badan dengan alat khusus yang diarahkan ke telapak tangan kiri, waktu mengantri tempat duduk sudah diatur dengan jarak tertentu, membawa KTP asli dan surat undangan dari desa dan dari kantor pos perihal penerimaan dana bantuan ..."

Hal senada juga disampaukan oleh Ibu DW selaku konsumen Kantor Pos Cabang Rembang menyatakan bahwa,

"... saya sudah empat tahun berjualan online dan selalu menggunakan jasa pos untuk mengirimkan paket karena lebih aman, paket tidak hilang/nyasar. Saya selalu mengantarkan paket-paket pesanan pelanggan langsung ke kantor Pos karena jarak kantor Pos dengan rumah saya dekat dengan memakai masker dan mencuci tangan pada wastafel yang telah disediakan sebelum memasuki kantor pos. Saya juga melihat para petugas loket pos yang semuanya memakai masker baik itu masker medik maupun masker kain, dan memakai sarung tangan. Tempat duduk saat mengantri di loket juga diberi tanda silang yang artinya tidak boleh kita mendudukinya yang tidak ada tanda silangnya kita boleh duduk ditempat duduk tersebut ..."

Pernyataan tersebut diperkuat oleh Bapak AR yang bertugas sebagai kepala P2 Dinas Kesehatan Kabupaten Rembang bahwa,

"... saya melihat di Kantor Pos Cabang Rembang sudah sangat baik penerapan protokol kesehatannya. Nanti jika Mbak ada datang kesana didepan kantor pos itu sudah tersedia wastafel dan sabun untuk cuci tangan, bangku tempat duduk sudah diberi tanda mana yang boleh ataupun tidak boleh diduduki, loket sudah diberi sekat dari mika bening, semua karyawan pos dan pelanggan pos sudah tertib memakai masker, ada penjadwalan berkala untuk penyemprotan disinfektan ..."

\section{Tantangan yang Dihadapi dalam Penerapan Kebijakan Pengelolaan Kesehatan Kerja dan Keselamatan} Kerja pada Masa Pandemi Covid-19 di Kantor Pos Cabang Rembang

Seringkali kita melihat bahwa kebijakan yang telah dibuat tidak sejalan dengan implementasi yang sebenarnya. Hal ini juga terjadi pada Kantor Pos Cabang Rembang Jawa Tengah. Beberapa implementasi tidak sesuai dengan kebijakan yang telah ditetapkan.

Ada berbagai faktor yang mempengaruhi penerapan implementasi protokol kesehatan tidak berjalan sebagaimana seharusnya. Faktor-faktor tersebut antara lain. Pertama, kedisiplinan. Tingkat kedisiplinan masyarakat Indonesia terhadap protokol kesehatan masih sangat kurang. Hal tersebut ditunjukkan dari data satuan tugas penanganan Covid-19 yang menunjukkan bahwa prosentase tingkat kepatuhan masyarakat untuk memakai masker adalah $58,32 \%$ dan presentase kepatuhan untuk menjaga jarak adalah 45,435 (https://covid-19.go.id, 2020);

Kedua, kesadaran. Sebagian besar masyarakat Indonesia beranggapan bahwa Covid-14 adalah sebuah konspirasi. Virus Covid-19 tidaklah berbahaya, merasa aman dari paparan virus Covid-19 karena Indonesia berada di daerah tropis dan menganggap orang Indonesia kuat-kuat adalah beberapa faktor yang mengakibatkan tingkat kesadaran masyarakat Indonesia akan pentingnya menerapkan protokol kesehatan masih sangat rendah (Yatima dkk, 2020).

Ketiga, pengawasan. Seringkali kita melihat protocol kesehatan 5M dapat dilaksanakan dengan baik apabila dilakukan pengawasan secara ketat, misalnya para pengguna jalan raya akan patuh memakai masker apabila ada patrol dan operasi dari pihak satpol PP dan polisi di jalan-jalan, para pelanggan pos akan memakai masker dengan baik dan benar karena apabila tidak memakai masker akan ditegur petugas pos dan dilarang memasuki kantor pos, konsumen kantor pos akan rajin mencuci tangan sebelum memasuki kantor pos apabila ditegus petugas pos, dan masyarakat Indonesia akan berfikir dua kali untuk bepergian ke luar kota karena harus ada beberapa persyaratan yang harus dipenuhi yang akan diperuksa oleh petugas di perbatasan kota. 
Keempat, adat kebiasaan atau budaya. Masyarakat Indonesia khususnya di kota Rembang memiliki kebiasaan budaya bersosialisasi dan berjabat tangan, misalnya arisan, pengajian, mencium tangan orang yang dihormati dan lebih tua, berjabat tangan apabila bertemu dengan orang yang dihormati dan dikenal. Hal-hal tersebut menjadikan penerapan social distancing sulit diterapkan.

Kelima, tingkat pendidikan. Rata-rata tingkat pendidikan di Indonesia khususnya di kota Rembang masih sangat rendah. Hal tersebut mengakibatkan mudahnya masyarakat untuk menerima berita-berita hoax, sulit untuk beradaptasi dengan kebiasaan baru, lebih ceroboh dan berdampak pada rendahnya penerapan protokol kesehatan.

Pertanyaan ketiga: apakah kendala yang dihadapi jika dipandang dari perspektif karyawan, manajemen, dan konsumen berkaitan dengan pengelolaan kesehatan kerja dan keselamatan kerja pada masa pandemi Covid-19?

Berikut kutipan-kutipan jawaban informan subjek:

Ibu DP sebagai kepala Kantor Pos Cabang Rembang menyatakan bahwa,

“... Dari yang saya lihat kendala yang dihadapi selama penerapan kebijakan protokol kesehatan dari sisi karyawan misalnya saya pada saat diwajibkan memakai masker sangat menggangu kenyamanan terutama saat berbafas dan berbicara, akan tetapi hal itu harus dilakukan demi kesehatan bersama dan lama-lama jadi terbiasa. Jika saya lihat dari sisi manajemen mungkin kendala untuk pengadaan sabun untuk cuci tangan, faceshield, masker medik, sarung tangan latek, dan handsanitiser karena tidak dianggarkan dalam budget. Jika saya lihat dari sisi konsumen antara lain yaitu sering kami jumpai konsumen datang ke kantor pos tidak memakai masker, tidak jarang juga konsumen masuk ke kantor pos lupa mencuci tangan terlebih dahulu padahal air mengalir dan sabun cuci tangan selalu tersedia, pada bangku tempat konsumen mengantri di loket sudah kami beri jarak dengan memberi tanda silang tidak boleh diduduki akan tetapi kadang masih sering diduduki bagi tempat duduk yang bertanda silang, pada saat pembagian Bantuan Sosial Tunai (BST) banyak diantara penerima dana bantuan yang menggeser bangku tempat duduk yang sudah kami susun berjarak satu meter karena bangku dari plastik enteng untuk dipindahkan supaya mereka dapat berdekatan dengan penerima dana bantuan yang lain untuk mengobrol, kultur budaya di Rembang yang jika bertemu berjabat tangan juga merupakan kendala penerapan kabijakan protokol kesehatan saya pernah mengalami sendiri sewaktu pembagian BST ada ibu-ibu mengajak bersalaman setelah beliau menerima dana tersebut diantara segan dan bimbang jika tidak dibalas jabat tangannya nanti dikira sombong dan jika saya sambut jabat tangannya saya menyalahi social distancing, akan tetapi saya balas dengan salam jabat tangan jarak jauh saya sampaikan untuk tidak berjabat tangan terlebih dahulu dimasa pandemi ini untuk kesehatan bersama ..."

Hal serupa juga disampaikan Bapak AL dan Ibu UM yang bertugas pelayanan loket Kantor Pos Cabang Rembang bahwa,

“... kendala dari kami petugas loket untuk penerapan kebijakan penerapan kesehatan tersebut adalah pada saat bertugas harus memakai masker terasa kurang nyaman saat bernafas, saat memakai masker jika berkomunikasi dengan pelanggan terkadang kurang jelas terdengar, kurang nyaman pada saat menghitung uang dan mengetik jika memakai sarung tangan latek, jika sering memakai handsanitiser setelah menghitung uang tangan terasa kaku/kasar. Barangkali jika dari manajemen pengadaan masker karena untuk masker medik diberikan pihak manajemen pada saat pembagian dana BST saja, jika tidak kami memakai masker kain beli sendiri, dan pengadaan sabun cuci tangan karena terkadang sabun cuci tangan habis tidak segera diisi ulang. Dari sisi konsumen menurut saya ada beberapa pelanggan pos datang tidak memakai masker, terkadang konsumen masuk ke kantor pos lupa mencuci tangan terlebih dahulu, dan terkadang ada konsumen yang sengaja duduk mendekati konsumen yang sedang mengantri hanya untuk mengobrol ..." 
Wahyuni Diah Ekasari: Pengelolaan Kesehatan dan ...

Berikut kutipan-kutipan jawaban informan Triangulasi:

Hal ini sesuai dengan yang disampaikan oleh Ibu RA sebagai penerima dana Bantuan Sosial Tunai dari Kementrian Sosial bahwa,

"... pas antri dana bantuan tahap siji, loro, telu dek kae ya akeh Mbak seng teko neng kantor pos ora maskeran akhire ya podo mulih otowo tuku masker supoyo iso melu antri maneh. Pas lungguh antri bangku digeser ben iso cedak karo kancane iso crita-crita lha nunggu suwi kan bosen juga Mbak. Nanging trus ditegur petugas yen ora oleh mindahi kursi sak karepe dewe. Kadang ngene iki yen ono wong seng kenal yo ngajak salaman Iho Mbak Iha piye neng ndesa kan biasane ngono leh Mbak."

Terjemahan:

"... pada saat mengantri dana BST tahap satu, dua, dan tiga dahulu ya banyak yang datang ke kantor pos tidak memakai masker, akhirnya mereka pulang ataupun membeli masker agar bisa kembali dalam antrian. Pada waktu mengantri tempat duduk seringkali dipindahkan agar berdekatan dengan temannya sehingga dapat bercerita karena bosan bila menunggu antrian lama hanya diam saja. Namun akhirnya ditegur oleh petugas pos jika dilarang memindahkan tempat duduk antrian sesuka hati. Terkadang saat ini jika ada yang kenal akan diajak bersalaman, mau bagaimana lagi Mbak sudah jadi kebiasaan masyarakat di desa seperti itu ..."

Bapak AS yang menjabat kepala P2 Dinas Kesehatan Kabupaten Rembang menyatakan bahwa, "... kendala yang dihadapi dalam penerapan kebijakan pengelolaan kesehatan dan keselamatan kerja pada masa pandemi Covid-19 ini tidak hanya dialami pada kantor pos saja tetapi semua kantor-kantor, pasar, restoran, tempat wisata dan hiburan, di jalan raya dan tempat umum lainnya. Dimana banyak masyarakat yang tidak disiplin dalam memakai masker, terkadang membawa masker tetapi tidak dipakai, memakai masker tetapi cara pakainya tidak benar, sarana cuci tangan tersedia tetapi lalai mencuci tangan, kultur budaya masyarakat Rembang yang suka bersosialisasi merupakan tantangan terberat dalam penerapan sosial distancing/jaga jarak dan kebiasaan masyarakat yang mengajak berjabat tangan saat bertemu, bahkan mencium tangan orang yang dianggap dihormati, serta tingkat pendidikan masyarakat Rembang yang tergolong rendah sangat sulit untuk memberi pengertian tentang bahaya pandemi glabal ini dan sangat sulit bagi masyarakat untuk dapat menerapkan protokol kesehatan yang telah dihimbau oleh pemerintah padahal protokol-protokol kesehatan tersebutlah cara untuk menghindari peyebaran virus ini. Masyarakat baru akan benar-benar mentaati protokol tersebut apabila ada pengawasan dari pihak tertentu misal ada patroli operasi polisi ataupun Satpol PP di jalan raya dan tempat-tempat umum tentang wajib masker, barulah masyarakat mau memakai masker karena takut kena sangsi dari polisi bukan karena alasan kesehatan bersama, atau ada petugas seperti satpam yang mengingatkan untuk memakai masker dan cuci tangan terlebih dahulu sebelum memasuki kantor. Kami sudah maksimal melakukan segala upaya pencegahan penyebaran virus Covid-19, tetapi bila tidak ada kerjasama dari semua masyarakat untuk patuh dan disiplin maka angka positif Covid-19 di Kabupaten Rembang akan terus naik ..."

\section{Solusi Guna Mengatasi Kelemahan-Kelemahan Pelaksanaan Pengelolaan Kesehatan dan Keselamatan Kerja pada Masa Pandemi Covid-19 di Kantor Pos Cabang Rembang}

Keselamatan kerja mengacu pada perlindungan karyawan dari cedera yang disebabkan kecelakaan yang berkaitan dengan pekerjaan. Hal-hal yang termasuk dalam cakupan definisi mengenai keselamatan ini adalah faktor-faktor yang berhubungan dengan stress berulang serta kekerasan di tempat kerja dan dalam rumah tangga. Sedangkan kesehatan di tempat kerja mengacu pada kebebasan dari penyakit fisik maupun emosional. Apabila perusahaan dapat menjalankan kesehatan dan keselamatan kerja sebagaimana mestinya, maka kesehatan dan keselamatan kerja para karyawan akan terpenuhi secara maksimum dan perusahaan akan memperoleh keuntungan maksimum. Panggabean (2016) menyatakan bahwa beberapa faktor yang mendukung pelaksanaan program kesehatan dan keselamatan kerja di tempat kerja diantaranya adalah adanya dukungan dari pimpinan puncak dan adanya pelatihan bagi semua karyawan untuk bertindak aman. Hal yang sama juga disampaikan oleh Kaynak, dkk (2016) yang 
mengatakan bahwa praktik-praktik kesehatan dan keselamatan kerja memiliki efek positif terhadap komitmen organisasi.

Kegiatan operasional Kantor Pos Cabang Rembang tetap berjalan seperti biasanya ditengah pandemi Covid-19 yang belum juga usai di Indonesia hingga saat ini. Seluruh manajemen Kantor Pos Cabang Rembang terus berkomitmen untuk menerapkan kebijakan kesehatan dan keselamatan kerja melalui penerapan protokol kesehatan 5M secara ketat. Hal ini bertujuan untuk mencegah, mengurangi, dan melindungi baik bagi karyawan dan pelanggan pos dari penyebaran pandemi virus Covid-19 di lingkungan Pos Indonesia. Sebagai salah satu langkah komitmen Pos Indonesia dalam menjalani kondisi adaptasi kebiasaan baru dan memutus rantai penyebaran virus Covid-19 tidak hanya dilakukan di lingkungan Pos Indonesia, yaitu dengan mengoptimalkan jasa kurir dan logistik dengan memanfaatkan layanan antar jemput/pickup service melalui petugas Oranger Pos.

Pertanyaan keempat: bagaimana solusi yang dirancang Kantor Pos Cabang Rembang untuk mengatasi kelemahan pelaksanaan kesehatan kerja dan keselamatan kerja pada masa pandemi Covid-19?

Berikut kutipan-kutipan jawaban informan subjek:

Hal ini sesuai dengan pernyataan Ibu DP selaku kepala Kantor Pos Cabang Rembang bahwa,

"... dari kendala yang kami hadapi tersebut kami terus mencoba mengingatkan pada karyawan pos akan pentingnya menjaga kesehatan dimasa pandemi ini dengan terus menerapkan semua protokol kesehatan dengan benar dan saling mengingatkan apabila ada yang lalai karena protokol tersebut berguna untuk melindungi karyawan, keluarganya, dan para pelanggan. Untuk pelanggan Pos juga kami selalu menegur apabila mereka datang ke kantor pos tidak memakai masker akan kami minta untuk pulang mengambil masker terlebih dahulu karena apabila tidak memakai masker maka tidak akan kami layani, mengingatkan pelanggan untuk mencuci tangan sebelum dan sesudah bertransaksi di kantor pos, apabila ada penerima dana pensiun dan BST yang menggeser tempat duduk pada saat mengantri akan kami tegur agar jangan menggeser tempat duduknya untuk tetap menjaga jarak, apabila ada yang mengajak berjabat tangan sebaiknya melakukan jabat tangan jarak jauh saja, masa pembayaran pensiunan diperpanjang dari tanggal 1 hingga 27 setiap bulannya, loket pos melayani pelangan dengan jam buka lebih lama (pada hari Senin-Jumat pukul 07.30 WIB-19.00 WIB, hari Sabtu pukul 07.30 WIB-16.00 WIB dan hari Minggu pukul 09.00 WIB-14.00 WIB), tentunya ada pembagian sif tugas pada petugas loket pos. Semua kami lakukan untuk dapat melayani pelanggan secara optimal dengan protokol yang ketat ..."

Bapak AL dan Ibu UM sebagai petugas loket Kantor Pos Cabang Rembang juga menyatakan bahwa, “... untuk mengatasi kendala pelaksanaan protokol kesehatan tersebut antara lain kami petugas loket akan menegur pelanggan yang datang tidak menggunakan masker, mengingatkan pelanggan untuk cuci tangan setelah melakukan transaksi di loket, diusahakan untuk tidak menyentuh meja ataupun pembatas mika yang ada di loket. Dari kami petugas pos berusaha membiasakan diri untuk disiplin memakai masker walaupun terasa kurang nyaman dan disiplin mencuci tangan dengan sabun karena dengan memakai masker kami melindungi diri kami sendiri, teman kerja kami, pelanggan, dan juga keluarga kami di rumah dari tertular virus Covid-19. Membuka loket sesuai jadwal yang telah ditetapkan manajemen kantor pos Rembang yaitu hari Senin-Jumat pukul 07.30 WIB-19.00 WIB, hari Sabtu pukul 07.30 WIB-16.00 WIB dan hari Minggu pukul 09.00 WIB-14.00 WIB, menjaga kerapian dan kebersihan lingkungan kerja kami salah satunya dengan membuang sampah pada tempatnya ..."

Ibu DP selaku kepala Kantor Pos Cabang Rembang menambahkan bahwa:

"... kami kantor pos Rembang tidak hanya berkomitmen untuk melaksanakan kebijakan protokol kesehatan 5M di lingkungan Pos saja, akan tetapi kami bekerjasama dengan pihak lain agar protokol kesehatan ini dapat dijalankan dengan baik untuk memutus rantai penyebarannya, antara lain : bekerjasama dengan dinas Dukcapil Kabupaten rembang (KK, KTP, maupun akta kelahiran yang sudah selesai diproses oleh Dinas Dukcapil akan kami pickup di kantor Dinas Dukcapil dan akan kami antar ke alamat penerima dan 
Wahyuni Diah Ekasari: Pengelolaan Kesehatan dan ...

pembayaran ongkos kirim ditanggung penerima dengan sistem COD), kami juga bekerja sama dengan SMA Negeri 3 Rembang untuk membagikan ijasah kelulusan kepada siswa kelas 12 ke alamat masing-masing siswa. Semua itu kami lakukan untuk berpartisipasi dalam memutus rantai penularan virus Covid-19 dengan mencegah adanya kerumunan. Jika kendala karena adanya pembatasan sosial berskala besar alhamdullilah kami tidak mengalami kendala, pengiriman berjalan lancar karena adanya pengecualian pembatasan sosial berskala besar terhadap logistik Pos sesuai dengan Permenkes No.9 Tahun 2020 sehingga kegiatan operasianal Kantor Pos Cabang Rembang dapat berjalan seperti biasanya sebelum adanya pandemi ..."

Berikut kutipan-kutipan jawaban informan Triangulasi:

Hal tersebut diperkuat dengan pernyataan Bapak AS selaku kepala P2 Dinas Kesehatan Kabupaten Rembang bahwa,

"... kendala-kendala tersebut kami atasi dengan cara terus mengingatkan masyarakat untuk disiplin memakai masker saat keluar rumah, ditempat kerja, maupun ditempat umum; rajin-rajin mencuci tangan dengan sabun dan air bersih yang mengalir; menjaga kesehatan dengan istirahat yang cukup, makan makanan yang sehat, dan minum vitamin; tidak keluar rumah jika memang betul-betul perlu; menjaga jarak/tidak berkerumun karena hal itu penting untuk memutus rantai penularan virus Covid-19, dan merupakan kebiasaan norma baru yang harus kita jalankan bersama-sama dengan disiplin. Mau tidak mau harus dijalankan karena sampai saat ini obat ataupun vaksin untuk Covid-19 jadi belum ada cara paling efektif adalah memutus rantai penularannya. Kami mensosialisasikannya dengan singkatan 5M, yaitu memakai masker, mencuci tangan dengan sabun, menjaga jarak aman, dan menjauhi kerumunan, serta mengurangi mobilitas ..."

Hal senada juga disampaikan oleh Ibu RA sebagai konsumen Kantor Pos Cabang Rembang penerima Dana Bantuan Sosial Tunai dari Kementrian Sosial menyatakan bahwa,

"... carane ben ora langgar aturan yo ojo nyepeleke aturan, iklas nganggo masker lan wisuh tangan, tuku masker seng kain ben iso dicuci dienggo maneh lan luwih murah regane, sementara eneng virus yo jogo jarak karo kancane nanging ojo ngasi musuhan ..."

Terjemahan:

"... cara agar tidak melanggar aturan tersebut adalah jangan menyepelekan aturan yang ada, iklas memakai masker dan mencuci tangan, membeli masker berbahan kain agar bisa dicuci dan dipakai lagi dan lebih murah harganya, untuk sementara waktu menjaga jarak dengan teman tetapi jangan sampai bermusuhan ..."

\section{KESIMPULAN}

Hasil penelitian menunjukkan implementasi protokol pencegahan penyebaran virus Covid-19 pada Kantor Pos Cabang Rembang dari hasil wawancara dengan informan subjek dan informan triangulasi adalah sebagai berikut. Pertama, memakai masker: semua karyawan Kantor Pos Cabang Rembang, tamu, dan juga pelanggan Kantor Pos Cabang Rembang diwajibkan memakai masker berlapis pada saat bekerja ataupun saat berada di lingkungan Kantor Pos Cabang Rembang. Kedua, mencuci tangan: semua karyawan Kantor Pos Cabang Rembang, tamu, dan juga pelanggan Kantor Pos Cabang Rembang diwajibkan mencuci tangan dengan sabun dan air yang mengalir (fasilitas wastafel dan sabun cuci tangan telah disediakan didepan dan disamping kantor Pos). Ketiga, menjaga jarak: petugas loket telah diatur tempat duduk nya menjaga jarak aman dan juga telah diberi sekat mika bening, kursi tunggu bagi pelanggan pos telah diberi tanda tempat duduk mana yang boleh dan tidak boleh diduduki, sedangkan tempat duduk bagi penerima dana bantuan sosial tunai telah diatur untuk menjaga jarak aman satu meter, tidak diperbolehkan menggeser/memindahkan tempat duduk antrian. Keempat, menjauhi kerumunan: adanya jasa Orager Pos untuk pickup service kiriman paket dan surat, bekerjasama dengan dinas ataupun sekolah untuk jasa pengantaran dokumen ataupun ijasah kelulusan, pembukaan 
pelayanan loket yang lebih panjang, pelayanan pembayaran dana pension dilaksanakan dari tanggal satu hingga tanggal 27 setiap bulannya. Kelima, mengurangi mobilitas: tidak mengadakan dinas luar kota selama masa pandemi, memaksimalkan jasa Orager Pos agar meminimalkan pelanggan pos untuk keluar rumah.

Implikasi praktis dari penelitian ini yaitu manajemen Kantor Pos Cabang Rembang untuk dapat membenahi diri sehubungan dengan pengelolaan kesehatan kerja dan keselamatan kerja dimasa pandemi virus Covid-19 serta memotivasi karyawan dan pelanggan Kantor Pos Cabang Rembang untuk selalu disiplin terhadap protokol kesehatan 5M demi kepentingan bersama. Salah satu cara untuk meningkatkan kepatuhan, kesadaran, dan kedisiplinan karyawan Kantor Pos Cabang Rembang terhadap protokol kesehatan adalah dengan memasukkan indikator protokol kesehatan $5 \mathrm{M}$ dalam penilaian kinerja karyawan Kantor Pos Cabang Rembang, melakukan pemeriksaan kesehatan secara berkala bagi karyawan Kantor Pos Cabang Rembang, dan memberikan suplemen makanan tambahan/vitamin secara rutin bagi karyawan Kantor Pos Cabang Rembang, serta memberikan vaksinasi Covid-19 secara gratis kepada karyawan Kantor Pos Cabang Rembang. Bagi pelanggan kantor pos cabang Rembang yang datang ke kantor pos tidak memakai masker, tidak diperintahkan untuk pulang akan tetapi dibagikan masker secara gratis serta diberikan arahan cara memakai masker yang baik dan benar, diberi himbauan kepada pelanggan pos untuk duduk ditempat duduk antrian yang teah disusun berjarak, dan memberikan informasi dan arahan untuk rajin mencuci tangan sebelum dan sesudah memasuki Kantor Pos Cabang Rembang.

\section{DAFTAR PUSTAKA}

Ahmad, I., Sattar, A., \& Nawaz, A. (2017). The Mediating Role Received Job Satisfaction In The Relationship Between Occupational Health And Safety And Employees Performance. Gomal Journal Of Medical Science, 15(1), 52-56.

Alfarizi, T. (2021, Januari 2). Protokol Kesehatan 5M dan Delapan Cara Pencegahan Terinfeksi Virus Covid-19. Pusat Analisis Determinan Kesehatan Kementrian Kesehatan Republik Indonesia. https://www.padk.kemkes.go.id/5-m-dimasa-pandemi-covid-19-di-indonesia.html

Dessler, G. (2016). Manajemen Sumber Daya Manusia. Jakarta: Salemba Empat.

Dinas Kesehatan Kabupaten Rembang. (2020). Perkembangan Kasus Aktif Covid-19 Kabupaten Rembang. http://www.covid19.rembangkab.go.id

Dinas Komunikasi dan Informatika. (2020). Jumlah PKM Penerima Dana Sosial Tunai Melalui Pos Rembang. https://rembangkab.go.id/bansos-bantuan-sosial/

Ekowati, V. M., \& Amin, F. M. (2018). The Effect Of Occupational Health And Safety On Employee Performance Trought Work Satisfaction. Advancess In Economic Business And Management Research, 101, 242-245.

Goniewicz, E. (2020). Current Response And Management Desicions Of The European Union To The Covid-19 Outbreak: A Review. Sustainability, 12(9), 3838. https://doi.org/10.3390/su12093838

Hamzah, A. (2020). Metode Penelitian Fenomenologi Kajian Filsafat \& Ilmu Pengetahuan. Batu Malang: Literasi Nusantara.

Hardum, S.E. (2020, Januari 12). Kecelakaan Kerja Masih Tinggi, Kemnaker Jangan Hanya Pentingkan Serimonial. Berita Satu. https://www.beritasatu.com/ekonomi/594901/kecelakaan-kerja-masih-tinggi-kemnaker-jangan-ha nya-pentingkan-serimonial 
Wahyuni Diah Ekasari: Pengelolaan Kesehatan dan ...

Kaynak, E. (2016). Effects Of Occupational Health And Safety Practicess On Organizational Commitment Work Alienation On Job Performance: Using The PLS-SEM Approach. International Journal of Business and Management.

Panggabean, S. (2016). Manajemen Sumber Daya Manusia. Tangerang Selatan: Universitas Terbuka.

Purnama, C. (2017). Emotional Inteligence And Occupational Health Impact On Employee Performance. MIX: Jurnal Ilmiah Manajemen, 7(3), 387-406.

Putri, D., Triatmanto, B., \& Setiyadi, S. (2018). The Effect Of Occupational Health And Safety Work Environment And Dicipline On Employee Performance In A Consumer Goods Company. International Conference on Industrial and System Engineering (IConISE), 337, 1-5. https://doi.org/10.1088/1757-899X/337/1/012036

Ramli, S. (2010). Sistem Manajemen Keselamatan \& Kesehatan Kerja OHSAS 18001. Jakarta: Dian Rakyat Ridley, J. (2018). Keselamatan Dan Kesehatan Kerja. Jakarta: Erlangga.

Safriansyah \& Naim, M. (2019). Analysis Of The Effect Of Occupational Safety And Safety On Employee Performance At The Majene District Disaster Management Office. Jurnal Manajemen IKM, 14(1), 62-68

Sembe, F. \& Ayuno, A. (2017). Effect Of Selected Occupational Health And Safety Management Practicess On Job Satisfaction Of Employees In University Campuses In Nakuru Town Kenya. Journal of Human Resource Management, 5(5), 70-77. https://doi.org/10.11648/j.jhrm.20170505.11

Sewu, G., Gyabeng, E., dadzie, A., \& Nkrumah, N. (2019). The Effects Of Occupational Health And Safety Management On Performance In The Banking Sector Ghana. International Bisnis Management, 14(10), 172-184. https://doi.org/10.5539/ijbm.v14n10p172

Wibowo, E., \& Utomo, H. (2016). Pengaruh Keselamatan Kerja dan Kesehatan Kerja Terhadap Kinerja Dengan Kepuasan Kerja Sebagai Variabel Intervening. Among Makarti: Journal of Economics \& Business, 9(1), 38-59. http://dx.doi.org/10.52353/ama.v9i1.126 